\title{
Chemical Deicer Poisoning was Suspected as a Cause of the 2005-2006 Wintertime Mortality of Small Wild Birds in Hokkaido
}

\author{
Tomohisa TANAKA ${ }^{1)}$, Ginpei TANOUE ${ }^{1}$, Masahiro YAMASAKI ${ }^{2)}$, Ikuo TAKASHIMA ${ }^{3)}$, Yoshihiro SAKODA ${ }^{4)}$, \\ Kenji OCHIAI $^{1)}$ and Takashi UMEMURA ${ }^{1) *}$ \\ ${ }^{1)}$ Laboratories of Comparative Pathology, ${ }^{2}$ Internal Medicine, ${ }^{3)}$ Public Health and ${ }^{4)}$ Microbiology, Graduate School of Veterinary \\ Medicine, Hokkaido University, N18 W9, Kita-ku, Sapporo 060-0818, Japan
}

(Received 3 August 2007/Accepted 1 February 2008)

ABSTRACT. Many small wild birds died in the 2005-2006 wintertime in Hokkaido. Thirteen birds were pathologically examined and it was attempted to detect West Nile and influenza viruses from their organs. Consecutive pathological changes were fresh hemorrhage and acute circulatory failure. Viral detections were negative. Selective occurrence in wintertime, literature review and the results of pathological and virological examinations suggested chemical deicer poisoning as the cause of wild bird death. Chicks treated orally with deicer showed acute death and their pathological changes were similar to those of the wild birds. Because the chicks showed significant elevation of plasma Na concentration, plasma electrolyte analysis of the affected wild birds might be crucial to confirm our tentative diagnosis.

KEY WORDS: chemical deicer poisoning, small wild birds, tree sparrows.

The mortality of small wildlife during winter has been reported in North America and Canada, and the cause has been attributed to salt poisoning due to the uptake of chemical deicers $[5,14]$. Small mammals and birds are sensitive to salt and poisoning tends to be the direct cause of death. Factors leading to poisoning include freezing temperature and heavy snowfall in winter, which result in a decrease in water supply and an increase in salt deposited due to stepped-up deicing operations on roads [5]. Recently, a report on the toxicity of sodium chloride $(\mathrm{NaCl})$ to house sparrows (Passer domesticus) was documented [3]. According to the report, sparrows orally given a lethal dose of $\mathrm{NaCl}$ showed rapid onset of depression, ataxia and death within $45 \mathrm{~min}$. In other reports $[1,13,14]$, the clinical signs of salt poisoning included an inability to stand, muscular weakness and convulsion, and necropsy revealed congestion and hemorrhage in various organs.

More than 750 small wild birds died in the 2005-2006 wintertime in Hokkaido, a cold district of Japan. The birds affected were tree sparrows (Passer montanus) and bush warblers (Cettia diphone), and the incidences of mortality were limited to the largest two cities in Hokkaido. Thirteen small wild birds ( 7 sparrows and 6 bush warblers) were submitted to pathological and virological examinations. Tissue samples were collected from the birds at necropsy, fixed in $20 \%$ neutral-buffered formalin and processed routinely for hematoxylin and eosin (HE) sections. Tissue pieces of the liver, kidneys and brain were submitted for the detection of West Nile virus (WNV), and those of the intestine and lungs were examined for influenza virus (IFV) infection. These examinations were performed by real-time PCR and virus

\footnotetext{
* Correespondence to: Umemura, T., Laboratory of Comparative Pathology, Graduate School of Veterinary Medicine, Hokkaido University, N18 W9, Kita-ku, Sapporo 060-0818, Japan.

e-mail: umemura@vetmed.hokudai.ac.jp
}

isolation in chicken embryo, respectively, as previously described $[10,12]$.

Gross and histological findings of the birds are listed in Table 1. At necropsy, 9 birds grossly showed various degrees of fresh pulmonary hemorrhage, and some tracheae were filled with blood (Fig. 1). Congestion and edema of the small intestinal wall was found in 3 sparrows and watery contents were retained in the intestine of another 3 sparrows. All the birds had no obvious external injuries and were not emaciated. Histologically, all the birds had congestion of various organs including the liver, kidneys, intestine, lungs and brain without any parenchymal cell damage. Congestion was most conspicuous in the lungs and brain. Three of 6 bush warblers had a small number of nematodes in the bile duct or intestines but tissue damage due to the infestation was minimal. None of the birds had inflammatory or necrotic lesions. Moreover, all the samples were negative for WNV and IFV. For experimental reproduction of the disease, 17, 2-day-old white leghorn chicks (mean body weight $38.4 \pm 2.4 \mathrm{~g}$ ) were treated orally with sodium chloride-magnesium chloride mixture $\left(\mathrm{NaCl}-\mathrm{MgCl}_{2}\right)$, one of the most popular chemical deicers in Hokkaido. Four or 5 chicks were given 0 (control), $0.05,0.1$ and $0.2 \mathrm{~g}$ of NaCl$\mathrm{MgCl}_{2}$, respectively, and were observed up to $12 \mathrm{hr}$ postexposure (PE) without a water supply, and all the surviving chicks were euthanized at the termination of the experiment. At necropsy, blood samples were collected and analyzed for plasma $\mathrm{Na}, \mathrm{Mg}$ and potassium $(\mathrm{K})$ concentrations using an autoanalyzer (FUJI DRI-CHEM 7000V, Japan). Tissue samples were processed for HE stains as above. The experiment was conducted following the guidelines of Hokkaido University Veterinary Medicine Animal Experiment Committee.

All the deicer-treated chicks showed diarrhea soon after treatment and the severity of diarrhea was dose-dependent. 
Table 1. Gross and histological lesions of small wild birds

\begin{tabular}{|c|c|c|c|c|c|c|}
\hline $\begin{array}{l}\text { Case } \\
\text { No. }{ }^{\text {a) }}\end{array}$ & $\begin{array}{l}\text { Date \& place } \\
\text { of collection }\end{array}$ & $\begin{array}{l}\text { Congestion of } \\
\text { lungs \& brain }\end{array}$ & $\begin{array}{l}\text { Pulmonary } \\
\text { hemorrhage }\end{array}$ & $\begin{array}{l}\text { Subcutaneous } \\
\text { hemorrhage }\end{array}$ & $\begin{array}{c}\text { Intestinal } \\
\text { congestion \& edema }\end{array}$ & $\begin{array}{l}\text { Watery feces } \\
\text { in intestine }\end{array}$ \\
\hline 1 & 2006.1 .12 & $\mathrm{NA}^{\mathrm{b})}$ & NA & - & + & - \\
\hline 2 & Asahikawa & NA & NA & - & + & - \\
\hline 3 & city & NA & NA & - & + & - \\
\hline 4 & $\begin{array}{l}2006.4 .19 \\
\text { Date city }\end{array}$ & + & - & - & - & - \\
\hline 5 & $\begin{array}{l}2006.4 .19 \\
\text { Ikeda town }\end{array}$ & + & + & + & - & + \\
\hline 6 & 2006.4 .28 & + & + & - & - & + \\
\hline 7 & Tomakomai city & + & + & - & - & + \\
\hline 8 & & + & + & + & - & - \\
\hline 9 & 2006.4 .21 & + & + & + & - & - \\
\hline 10 & Matsumae & + & + & + & - & - \\
\hline 11 & town & + & + & + & - & - \\
\hline 12 & & + & + & + & - & - \\
\hline 13 & & + & + & - & - & - \\
\hline
\end{tabular}

a) Case Nos. 1-7: tree sparrows, Case Nos. 8-13: bush warblers.

b) Not available for analysis.
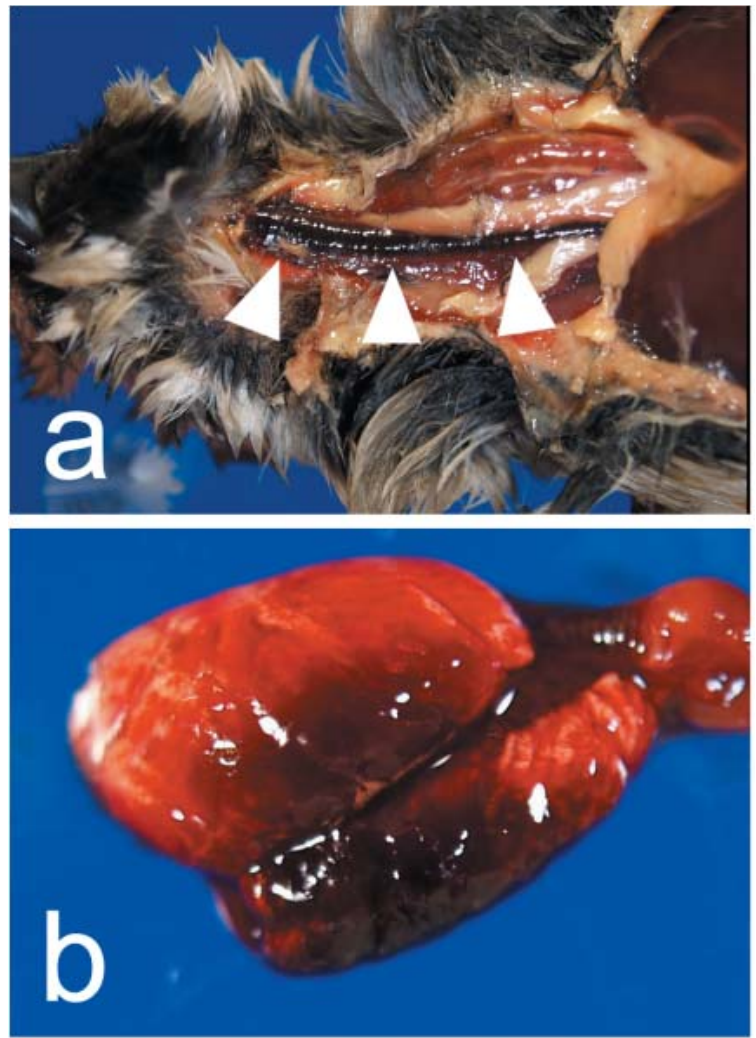

Fig. 1. Gross appearances of sparrows. a) The trachea filled with blood (arrow heads), Case No. 6. b) Pulmonary hemorrhage, Case No. 7.

One of 4 chicks in the 0.1 g group (chick No. 10) and 3 of 5 chicks in the $0.2 \mathrm{~g}$ group (chick Nos. 15-17) showed severe depression and were euthanized at $2 \mathrm{hr}$ PE. The remaining
Table 2. Lesions of $\mathrm{NaCl}-\mathrm{MgCl}_{2}$-treated chicks

\begin{tabular}{|c|c|c|c|c|c|}
\hline \multirow{2}{*}{$\begin{array}{l}\text { Chick } \\
\text { No. }\end{array}$} & \multirow{2}{*}{$\begin{array}{l}\text { Dose } \\
(\mathrm{g})\end{array}$} & \multirow{2}{*}{$\begin{array}{c}\text { Termina- } \\
\text { tions }\end{array}$} & \multicolumn{2}{|c|}{ Congestion } & \multirow{2}{*}{$\begin{array}{l}\text { Edema of } \\
\text { the gizzard }\end{array}$} \\
\hline & & & Lungs & Brain & \\
\hline 1 & \multirow{4}{*}{0} & $\mathrm{~S}^{\mathrm{a})}$ & _b) & - & - \\
\hline 2 & & $\mathrm{~S}$ & - & - & - \\
\hline 3 & & $\mathrm{~S}$ & - & - & - \\
\hline 4 & & $\mathrm{~S}$ & - & - & - \\
\hline 5 & \multirow{4}{*}{0.05} & $\mathrm{~S}$ & - & - & - \\
\hline 6 & & $\mathrm{~S}$ & + & - & + \\
\hline 7 & & S & - & + & + \\
\hline 8 & & $\mathrm{~S}$ & - & + & + \\
\hline 9 & \multirow{4}{*}{0.1} & $\mathrm{~S}$ & + & + & - \\
\hline 10 & & $\mathrm{D}(2)$ & ++ & ++ & ++ \\
\hline 11 & & S & - & + & - \\
\hline 12 & & $\mathrm{~S}$ & - & - & - \\
\hline 13 & \multirow{5}{*}{0.2} & D (7) & ++ & + & - \\
\hline 14 & & $\mathrm{D}(7)$ & ++ & ++ & + \\
\hline 15 & & $\mathrm{D}(2)$ & ++ & +++ & - \\
\hline 16 & & $\mathrm{D}(2)$ & ++ & + & - \\
\hline 17 & & $\mathrm{D}(2)$ & ++ & ++ & - \\
\hline
\end{tabular}

a) S: Survived (euthanized at $12 \mathrm{hr}$ PE), D: Died. Numbers in parenthesis mean post-exposure time (hr) at collapse.

b) -: normal, +: mild, ++: moderate, +++ : severe.

2 chicks in the $0.2 \mathrm{~g}$ group (chick Nos. 13, 14) also showed similar clinical signs at $7 \mathrm{hr}$ PE (Table 2). The other deicertreated chicks showed mild to moderate depression but survived until the end of the experiment. At necropsy, 3 chicks in the 0.2 g group (chick Nos. 15-17) had watery intestinal contents consistent with severe diarrhea. One chick in the 0.1 g group (chick No. 10) had moderate gizzard edema and other deicer-treated chicks also had minimum to mild edema of the gizzard (Table 2). Histologically, deicer-treated chicks showed various degrees of acute systemic congestion most prominently in the lungs and brain (Table 2, Fig. 2) as 
previously reported $[1,14]$. In contrast to other reports $[6$, $9,11]$, no hepatocellular, renal or neuronal degeneration was observed. The plasma Na concentration increased with treatment, but $\mathrm{Mg}$ and $\mathrm{K}$ concentrations did not increase significantly (Fig. 3).

Postmortem examinations of the wild birds revealed that
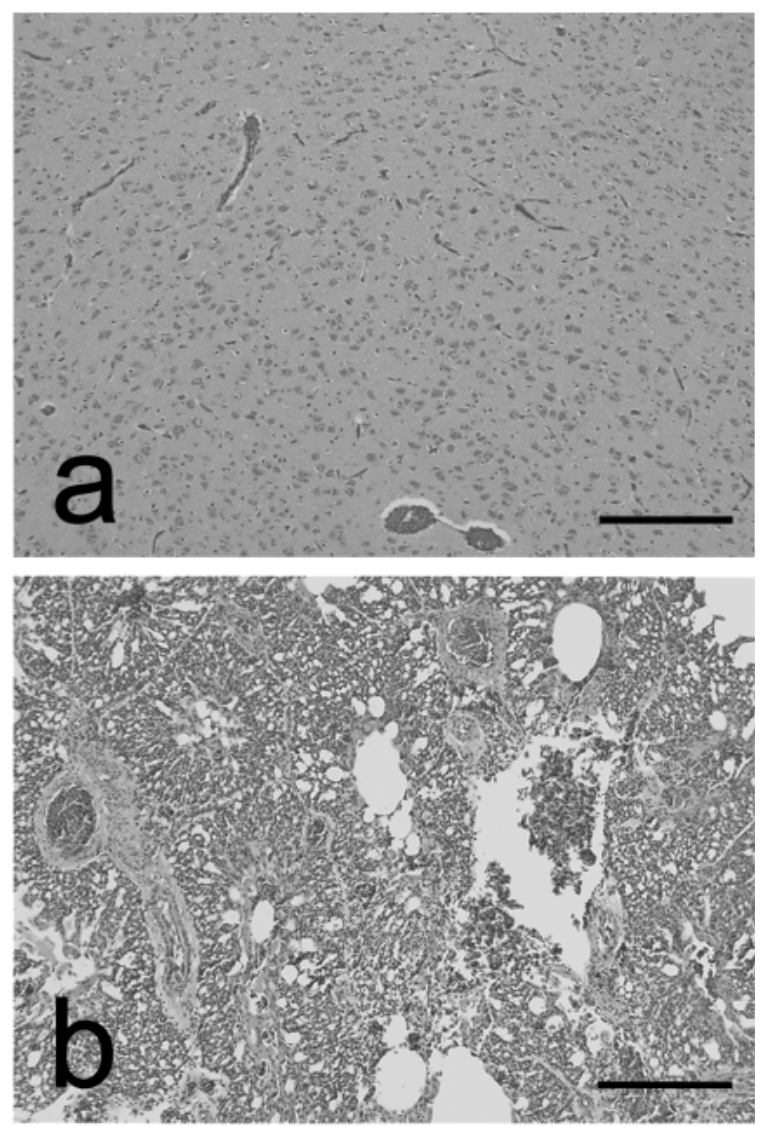

Fig. 2. Histological appearances of $\mathrm{NaCl}-\mathrm{MgCl}_{2}$-treated chicks. a) Pulmonary congestion, chick No. 14, HE stain. b) Cerebral congestion, chick No. 14, HE stain. Bar $=200 \mu \mathrm{m}$. significant lesions were systemic congestion and pulmonary fresh hemorrhage. Parasitic infestation of the birds was inconsistent and considered as an incidental finding. Pathological examination suggested that the birds died due to acute circulatory failure caused by chemical deicer poisoning $[1,5,13,14]$, and infection, starvation or trauma might not have caused death. Both the wild birds and chicks showed the accumulation of watery intestinal contents and systemic congestion. Some chicks showed edematous thickening of the gizzard wall, but no change was observed in the wild birds. Lesions from $\mathrm{NaCl}$ (chemical deicer) poisoning have been reported to be transient and may disappear after death [3]. In the winter of 2005-2006, we experienced relatively heavy snowfall and low temperature in compare with ordinal years. Moreover, the death of small wild birds occurred only in wintertime in large cities where chemical deicers are sparged more heavily than in rural areas, consistent with the epidemiological characteristics of chemical deicer poisoning.

In deicer-treated chicks, the plasma $\mathrm{Na}$ concentration significantly increased and $200 \mathrm{mmol} / l$ was lethal, consistent with previous reports $[3,4]$. The uptake of $0.1 \mathrm{~g}$ deicer was lethal to chicks, and was equivalent to $0.07 \mathrm{~g}$ for sparrows on a body weight basis. Sparrows prefer angular yellowish chemical deicer and can take lethal amount of deicer $[2,7$, 8]. Although we could not quantify the plasma Na concentration of dead birds, the present findings suggest chemical deicer poisoning as a possible cause of wild bird death.

ACKNOWLEDGMENT. We thank Dr. T. Hongo, local government of Hokkaido prefecture, for providing the cases, epidemiological data and chemical deicer.

\section{REFERENCES}

1. Austic, R. E. and Scott, M. L. 1984. pp. 38-64. In: Diseases of Poultry, 8th ed. (Hofstad, M. S. ed.), Iowa State University Press, Iowa.

2. Best, L. B. and Gionfriddo, J. P. 1994. Wilson Bulletin. 106: 689-695.

3. Bollinger, T. K., Mineau, P. and Wickstrom, M. L. 2005. J. Wildlife Dis. 41: 363-370.
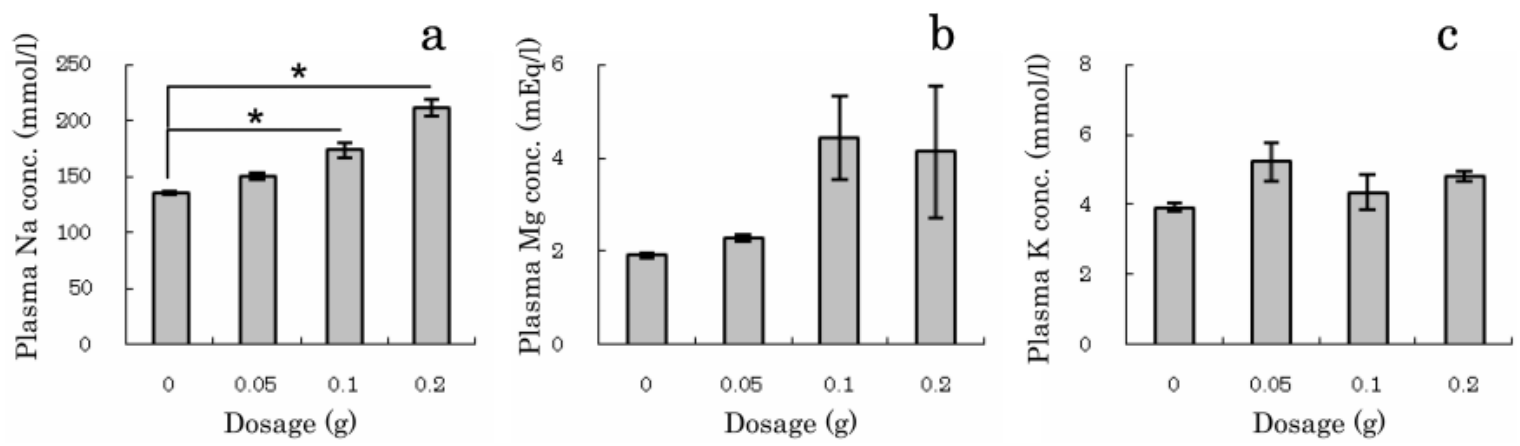

Fig. 3. Effect of $\mathrm{NaCl}-\mathrm{MgCl}_{2}$-treatment on plasma $\mathrm{Na}(\mathrm{a}), \mathrm{Mg}$ (b) and $\mathrm{K}$ (c) concentrations. Each value represents mean \pm standard error of 4 or 5 chicks Statistical analyses were performed by ANOVA with Dunnett's multiple comparison of means test. Asterisks mean $P<0.01$. 
4. Dawson, W. R., Shoemaker, V. H.,Tordoff, H. B. and Borut, A. 1965. Auk 82: 606-623.

5. D'Itri, F. M. 1992. pp. 65-105. In: Chemical Deicers and the Environment (D'Itri, F. M. ed.), Lewis Publishers, Florida.

6. Doll, E. R., Hull, F. E. and Insko, W. R. 1946. Vet. Med. 41: 361-363.

7. Gionfriddo, J. P. and Best, L. B. 1995. Condor 97: 57-67.

8. Gionfriddo, J. P. and Best, L. B. 1996. J. Wildlife Manage. 60: 836-842.

9. Mohanty, G. C. and West, J. L. 1969. Avian Dis. 13: 762-773.

10. Okazaki, K., Takada, A., Ito, T., Imai, M., Takakuwa, H., Hatta, M., Ozaki, H., Tanizaki, T., Nagano, T., Ninomiya, A.,
Demenev, V. A., Tyaptirganov, M. M., Karatayeva, T. D., Yamnikova, S. S., Lvov, D. K. and Kida, H. 2000. Arch. Virol. 145: 885-893.

11. Paver, H., Robertson, A. and Wilson, J. E. 1953. J. Comp. Pathol. 63: 31-47.

12. Shirato, K., Miyoshi, H., Kariwa, H. and Takashima, I. 2005. J Virol. Methods 126: 119-125.

13. Stolley, D. S. and Meteyer, C. U. 2004. J. Wildlife Dis. 40: 571-574.

14. Trainer, D. O. and Karstad, L. 1960. J. Am. Vet. Med. Assoc. 136: 14-17. 